\section{Acta stomatologica Croatica i PubMed Central}

Acta stomatol Croat. 2016;50(2):106-107.

DOI: $10.1564 /$ asc $50 / 2 / 1$

\section{Sažetak}

Dana 15. travnja obilježena je 50. godišnjica kontinuiranog izlaženja časopisa Acta stomatologica Croatica (ASCRO). Prigodna svečanost održana je u velikoj dvorani Hrvatskoga liječničkog zbora u nazočnosti mnogobrojnih uglednih gostiju iz područja biomedicine. 0 povijesti časopisa govorio je nekadašnji urednik Goran Knežević (uređivao ga je od 1996. do 2006.) te trenutačni urednik Hrvoje Brkić koji je predstavio sve aktualnosti u vezi s elektroničkim uređivanjem časopisa te njegovu trenutačnu indeksaciju. Nekoliko dana poslije uredništvo je obaviješteno da je ASCRO od 48. volumena uvršten u PubMed Central, što je članovima uređivačkog kolegija i uredniku dalo daljnji poticaj da ASCRO bude još kvalitetniji i citiraniji.

Dana 15. travnja obilježena je 50. godišnjica kontinuiranog izlaženja časopisa Acta stomatologica Croatica (ASCRO). Prigodna svečanost održana je u velikoj dvorani Hrvatskoga liječničkog zbora u nazočnosti mnogobrojnih uglednih gostiju iz područja biomedicine. O povijesti časopisa govorio je nekadašnji urednik Goran Knežević (uređivao ga je od 1996. do 2006.) te trenutačni urednik Hrvoje Brkić koji je predstavio sve aktualnosti u vezi s elektroničkim uređivanjem časopisa te njegovu trenutačnu indeksaciju. Povelje časopisa Acta stomatologica Croatica dobili su prof. dr. sc. Ana Cekić - Arambašin za najproduktivniju autoricu - objavila je 80 članaka u proteklih 50 godina, te prof. dr. sc. Goran Knežević za desetogodiš̌nje uređivanje ASCRO-a i uvođenje engleskog jezika. Povelje su također dobili knjižničarka Vesna Borić, doc. dr. sc. Ivan Galić i dr. med. dent. Gabrijela Leskovar za elektroničko arhiviranje cjelokupne građe časopisa (slike 1., 2., 3.).

Nekoliko dana poslije uredništvo je obaviješteno da je ASCRO od 48. volumena uvršten u PubMed Central, što je članovima uređivačkog kolegija i uredniku dalo daljnji poticaj da ASCRO bude još kvalitetniji i citiraniji.

PubMed Central (PMC) besplatan je digitalni repozitorij koji arhivira javno dostupne full-text znanstvene članke objavljene u biomedicinskoj literaturi. To je jedna od glavnih istraživačkih baza podataka u sklopu paketa resursa koje je razvio Nacionalni centar za biotehnološke informacije (NCBI). Podnesci u PMC-u prolaze indeksiranje i oblikovanje postupaka koji rezultiraju poboljšanim metapodatcima, te su jedinstveni identifikatori obogaćeni XML strukturiranim podatcima.

Od veljače 2014. PMC-ov arhiv sadržava više od 2,9 milijuna članaka, a tekstove dostavljaju izravno izdavači ili autori koji pohranjuju svoje rukopise u repozitorij otvorenog pristupa. Od godine 2014. dijelom PMC-ova arhiva postala je i Acta stomatologica Croatica.

\section{Acta stomatologica Croatica and PubMed Central}

Abstract

April 152016 marked the 50th anniversary of continuous publishing of the journal Acta stomatologica Croatica (ASCRO). The celebration was held in the great hall of the Croatian Medical Association, with numerous guests from the biomedical field. The history of the journal was presented by Goran Knežević (editor-in-chief 1996-2006) and Hrvoje Brkić (current editor-in-chief), who presented all the current information on the electronical editing and its current indexation. Only a few days later, the Editorial Office received the information that ASCRO has been included in PubMed Central since volume 48, an impulse for the members of the Editorial Board and the Editor-in-Chief to make ASCRO better and more cited

April 152016 marked the 50th anniversary of continuous publishing of the journal Acta stomatologica Croatica (ASCRO). The celebration was held in the great hall of the Croatian Medical Association, with numerous guests from the biomedical field. The history of the journal was presented by Goran Knežević (editor-in-chief 1996-2006) and Hrvoje Brkić (current editor-in-chief), who presented all the current information on the electronical editing and its current indexation. Acta stomatologica Croatica certificated were awarded to Ana Cekić-Arambašin (the most prolific author, with 80 articles in 50 years), and Goran Knežević (for his 10-year editorial work and introduction of English). Certificated were also awarded to Vesna Borić, Ivan Galić and Gabrijela Leskovar, for their achievement in the archiving of the whole journal (figures 1, 2, 3).

Only a few days later, the Editorial Office received the information that ASCRO has been included in PubMed Central since volume 48, an impulse for the members of the Editorial Board and the Editor-in-Chief to make ASCRO better and more cited.

PubMed Central (PMC) is an open digital repository that archives open full text scientific articles in the biomedical field. It is one of the most important search databases in the resource package that was developed by te National center for biotechnological information (NCBI). Items submitted to PMC go through indexation and reshaping that yield improved metadata, and they have unique identificators that have added XML structured data.

Since February 2014 PMC archives include more than 2.9 million articles, with texts submitted by either authors or publishers. ASCRO is part of te PMC archives since 2014.

\footnotetext{
Hrvoje Brkić Glavni urednik
} 


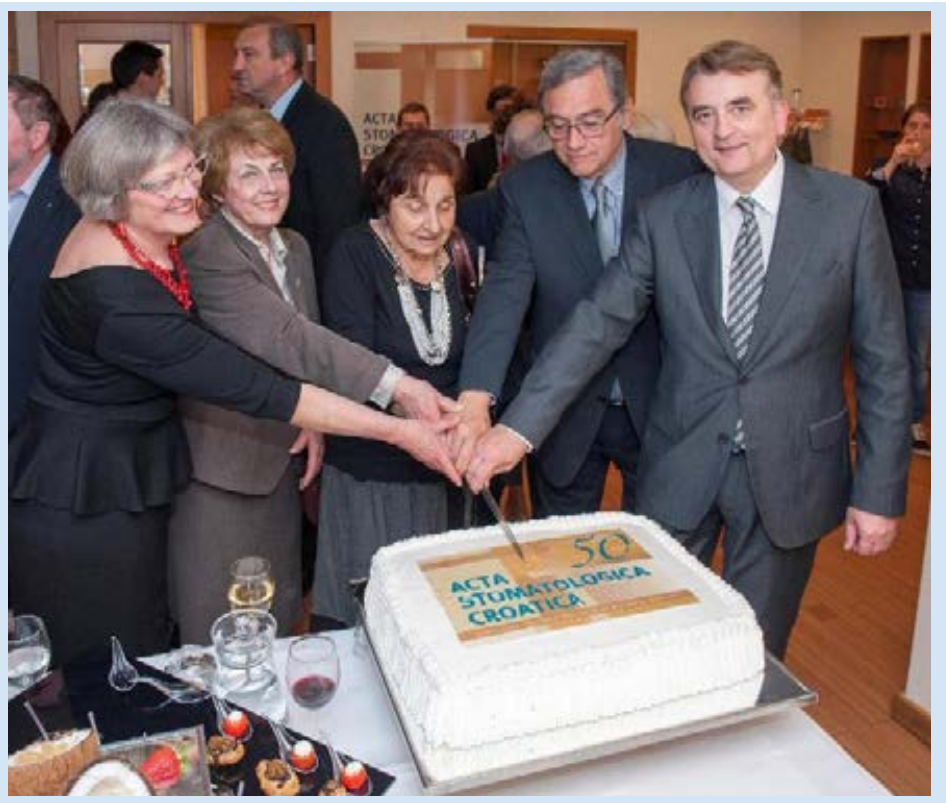

Slika 1. S lijeva na desno: Vesna Borić, prof. dr. sc. Ana Cekić-Arambašin, Lidija Berić, prof. dr. sc. Goran Knežević, prof. dr. sc. Hrvoje Brkić

Figure 1 From left to right: Vesna Borić, professor Ana Cekić-Arambašin, Lidija Berić, professor Goran Knežević, professor Hrvoje Brkić

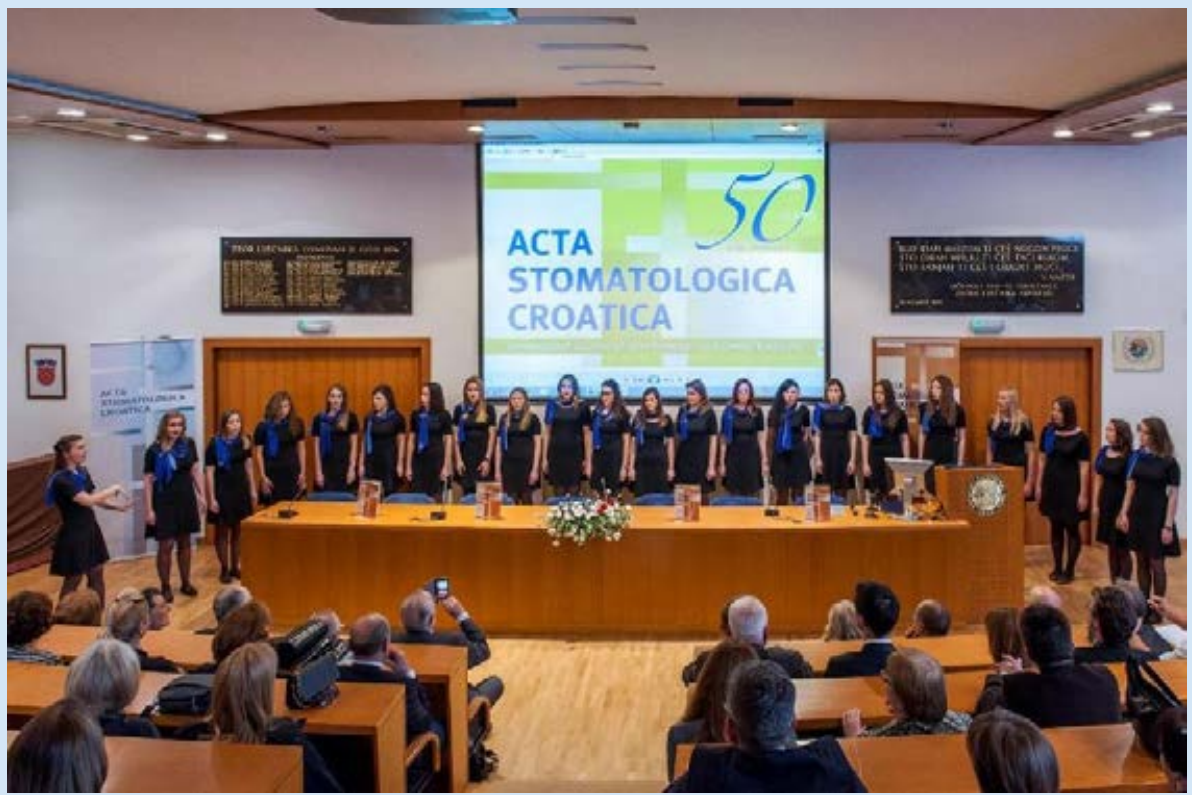

Slika 2. Studentski zbor "Zubor" Stomatološkog fakulteta na 50. godišnjici.

Figure 2 Student choir "Zubor" of School of Dental Medicine in the ceremony of $50^{\text {th }}$ anniversary.
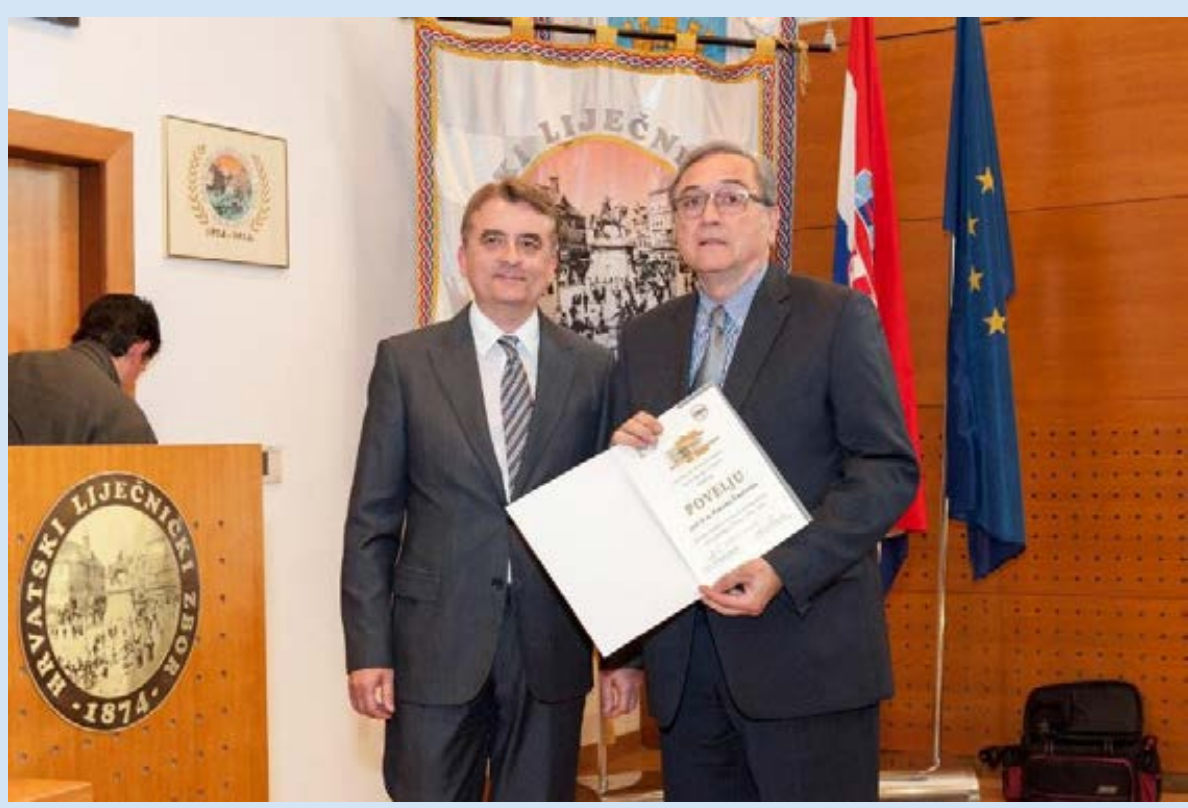

Slika 3. Dva urednika. Goran Knežević (desno) od 1996. do 2006. i Hrvoje Brkić (lijevo) - sadašnji urednik.

Figure 3 Two editors. Goran Knežević (right) from 1996-2006, and Hrvoje Brkić (left) - the current editor. 